\title{
Vitamin D and Mammographic Findings
}

\author{
Vitamin D und Mammografiebefunde
}

Authors

Affiliations
J. Riedel ${ }^{1}$, L. Straub ${ }^{1}$, J. Wissing ${ }^{1}$, A. Artmann ${ }^{2}$, M. Schmidmayr ${ }^{1}$, M. Kiechle ${ }^{1}$, V. R. Seifert-Klauss ${ }^{1}$

${ }^{1}$ Frauen- und Poliklinik der TU München, Munich

2 Praxis für Brustgesundheit, Munich
Key words

- mammographic density

- vitamin D

- calcitriol

- breast cancer risk

Schlüsselwörter

- Brustdichte

- Vitamin D

- Calcitriol

- Brustkrebsrisiko

received $\quad 20.11 .2015$

revised 7.4 .2016

accepted 7.4.2016

\section{Bibliography}

DOI http://dx.doi.org/

10.1055/s-0042-106208

Geburtsh Frauenheilk 2016; 76:

570-578 ๑ Georg Thieme

Verlag KG Stuttgart · New York .

ISSN 0016-5751

\section{Correspondence}

\section{Dr. Vanadin Regino}

Seifert-Klauss, MD PhD

Frauenklinik und Poliklinik

der TU München

Gyn. Ambulanz

Klinikum rechts der Isar

Ismaninger Straße 22

81675 Munich

endokrinologie@|rz.tum.de

\section{Abstract \\ $\nabla$}

Introduction: Pleiotropic immune-modulatory and anti-proliferative effects of vitamin D and hopes to stop cancerogenesis have led to an increased interest in possible reduction of breast cancer with higher vitamin D levels. Mammographic density is an established risk factor for breast cancer risk, and its association with serum vitamin D is complex, as recent studies have shown.

Patients and Methods: In this cross-sectional study, 1103 participants were recruited in the breast diagnostic unit of the Klinikum rechts der Isar, TU Munich. A standardised questionnaire and blood samples for 25-OH-vitamin D were taken on the day of mammography. Histologic results of biopsies in suspicious mammographies were documented.

Results: In the 1090 data-sets analysed, vitamin D-deficiency was common among women under 40. Highest vitamin D values were observed in participants aged 60-69 years, but average values for all age cohorts were below $20 \mathrm{ng} / \mathrm{ml}$ of vitamin D. $15.6 \%$ of all participants had very low vitamin D values (<10 ng/ml), 51.3\% were vitamin Ddeficient (10-19 ng/ml) and only $5.7 \%$ were above $30 \mathrm{ng} / \mathrm{ml}$, i.e. showed sufficient vitamin D. Patients with malignant results had vitamin $\mathrm{D}<10 \mathrm{ng} / \mathrm{ml}$ more often (16.9\%; $\mathrm{p}=0.61$ ), and only $3.4 \%$ in this group had sufficient vitamin D supply (> $30 \mathrm{ng} / \mathrm{ml}$ ). There were no significant differences in vitamin D-levels between density groups according to the American College of Radiology (ACR) criteria.

Conclusion: Vitamin D values were lower than in comparable US women. Up to now, there is no direct clinical evidence for a relationship between the risk for breast cancer and a specific vitamin D value.

\section{Zusammenfassung \\ $\nabla$}

Einleitung: Vitamin D hat bekanntlich eine pleiotrope, immunmodulierende und antiproliferative Wirkung. Die Suche nach Präventivmaßnahmen, welche die Entstehung von Brustkrebs verhindern könnten, hat das Interesse an potenziellen Zusammenhängen zwischen Brustkrebsrisiko und Höhe des Vitamin-D-Spiegels gesteigert. Hohe Brustdichte ist ein etablierter Risikofaktor für Brustkrebs, aber neuere Studien haben gezeigt, dass die Zusammenhänge zwischen Brustdichte und Vitamin-D-Spiegel im Blut komplex sind.

Patientinnen und Methoden: Für diese Querschnittsstudie wurden in der Abteilung für Mammadiagnostik des Klinikums rechts der Isar der TU München 1103 Teilnehmerinnen rekrutiert. Alle Teilnehmerinnen wurden anhand eines standardisierten Fragebogens am Tag der Mammografie befragt, und bei allen wurden Blutproben zur Bestimmung des 25-OH-Vitamin-D-Spiegels entnommen. Die histologischen Biopsiebefunde nach auffälliger Mammografie wurden dokumentiert.

Ergebnisse: Nach Analyse der 1090 Datensätze stellte sich heraus, dass Frauen unter 40 Jahren häufig unter Vitamin-D-Mangel litten. Die höchsten Vitamin-D-Werte fanden sich bei Frauen im Alter von 60-69 Jahren, aber der Mittelwert für alle Altersgruppen lag unter $20 \mathrm{ng} / \mathrm{ml}$ Vitamin D. Bei 15,6\% der Teilnehmerinnen war der VitaminD-Serumspiegel sehr niedrig ( $<10 \mathrm{ng} / \mathrm{ml}$ ); 51,3\% der Teilnehmerinnen hatten einen Vitamin-DMangel (10-19 ng/ml), und nur 5,7\% hatten einen Vitamin-D-Wert von mehr als $30 \mathrm{ng} / \mathrm{ml}$ bzw. hatten einen ausreichend hohen Vitamin-D-Spiegel im Blut. Patientinnen mit malignen Befunden hatten häufiger $(16,9 \%$; $\mathrm{p}=0,61)$ einen Vitamin-DSerumspiegel von < $10 \mathrm{ng} / \mathrm{ml}$; nur bei $3,4 \%$ der Frauen in dieser Gruppe war die Versorgung mit Vitamin D (> $30 \mathrm{ng} / \mathrm{ml}$ ) ausreichend. Es gab keine 
signifikanten Unterschiede in der Höhe des Vitamin-D-Spiegels zwischen den Gruppen mit verschiedener Brustdichte entsprechend den Kriterien des American College of Radiology (ACR). Schlussfolgerung: Es gibt bis dato keinen direkten klinischen Nachweis für einen Zusammenhang zwischen dem Risiko, an Brustkrebs zu erkranken, und einer bestimmten Höhe des Vitamin-D-Serumspiegels.

\section{Introduction}

$\nabla$

The possible prevention of breast cancer by detection of risk factors for this disease in women is the subject of many recent studies. New insights into pleiotropic immunomodulatory and antiproliferatory effects of vitamin D and the associated hopes to stop cancerogenesis have led to an increased interest in vitamin $\mathrm{D}$ in this context [1]. Up to now, conflicting study results disagree on the relationship between serum 25-hydroxyvitamin D values and the risk of developing breast cancer.

Vitamin D is a liposoluble vitamin and stems from the steroidal hormone cholesterol. As it is produced endogenously, it is not an essential vitamin by the strict definition. Thus, it is more accurately a pro-vitamin-hormone. The active form calcitriol, or $1 \alpha, 25$ hydroxyvitamin $\mathrm{D}$ is synthesized in the kidney from 25 $\mathrm{OH}$-vitamin D (see $\bigcirc$ Fig. $\mathbf{1}$ a and $\mathbf{b}$ ) by the enzyme 25-hydroxyvitamin $\mathrm{D}_{3}-1 \alpha$-hydroxylase ( $1 \alpha-\mathrm{OH}$-ase or CYP27B1) [2-4]. 24hydroxylase (CYP24A1) inactivates this active metabolite by reduction. The latter enzyme is self-induced by calcitriol, thereby representing a self-limiting mechanism in the metabolic regulation of vitamin D.

Experimental studies have sparked the hope that vitamin D in extrarenal tissues also plays an important role in carcinogenesis. It has been hypothesized that the effective metabolite calcitriol may be responsible for a pleiotropic anticancer effect.

Welsh et al. investigated the impact of the vitamin $\mathrm{D}$ receptor (VDR) on cell proliferation. Deletion in the VDR gene led to an increased proliferation rate and increased oxidative stress to the DNA in vitro and in mice [5]. 1,25VitD3 inhibited the growth of breast cancer cells in vitro as well as in vivo and induced apoptosis [6-9]. In addition, vitamin D reduced the activity of serin- and metalloproteases and prevented invasion and growth of metastatic cancer cells in vitro [10]. The enzyme 24-hydroxylase (CYP24A1), which is important for inactivation of the active form $1 \alpha, 25$, dihydroxy-vitamin $\mathrm{D}$, is expressed in the breast as well as in other extrarenal tissues [11]. This allows local regulation of vitamin D metabolism, in conjunction with the vitamin D receptor, which is expressed in many organs [12-14].

In breast tissue, $1 \alpha,-25$-dihydroxy-vitamin $\mathrm{D}$ also interacts with the estrogen receptor (ER). The promotor region of the ER exhibits two negative vitamin $\mathrm{D}$ response elements (= nVDREs), which both mediate calcitriol transrepression. The vitamin $\mathrm{D}$ receptor (VDR) can bind and - in the presence of calcitriol - suppress ER expression and estrogen-mediated signaling. For maximal inhibition of ER expression by calcitriol, both nVDREs are required [15]. Calcitriol may also directly impact on estrogen biosynthesis by inhibition of the p450 aromatase. Calcitriol intake in mice with human breast tissue implants led to a lower expression of aromatase mRNA in the carcinomas as well as in the surrounding aliphatic breast tissue without influencing the aromatase expression in the ovaries. Furthermore a decrease of prostaglandine levels which normally stimulate aromatase, was observed. These are two further mechanisms of vitamin D which are possibly rele- vant in carcinoma prevention: a direct suppression of aromatase transcription through the binding of calcitriol to vitamin D response elements in the promoter region of the CYP 19 gene, as well as an indirect effect through the suppression of prostaglandin synthesis. A combination of aromatase inhibitors and vitamin D supplementation has been hypothesized to be advantageous in breast cancer therapy [16]. However, no clinical data on this combination exist.

With increasing density of the breast, the sensitivity of mammography decreases to $\leq 50 \%$. A meta-analysis by McCormack et al. showed a 4 to 6 times higher risk of breast cancer for women with a higher density of the breast compared with women with a lower density of the breast [17]. One reason for this could be the fact that in a denser breast tissue, there are proportionally more stromal and epidermal cells from which breast cancer could arise than in a breast with fatty involution. Both increased body-massindex and hormone replacement therapy influence breast density, and lower vitamin D concentrations have also been associated with a higher breast density. In this cross-sectional study, 25 hydroxyvitamin D-serum levels were measured in women undergoing mammography and the association of vitamin D with lifestyle and risk factors as well as the mammographic findings, including mammographical density (ACR classification) were documented. Differences in vitamin D distribution, menopausal status, UV-light exposition and use of sun protection lotions, vitamin D intake by supplementation and food, body mass index (BMI), and physical activity were also analyzed for women with benign clinical findings as opposed to women with malignant histologic results.

\section{Patients and Methods}

\section{$\nabla$}

Recruitment, inclusion and exclusion criteria

Participants for the study were recruited from October 2009 until June 2010 by the gynecological endocrinology team in the breast diagnostic unit of the Klinikum rechts der Isar, TU Munich. Patients attended the breast diagnostic unit both for breast screening and for suspicious clinical findings, including dermatological peculiarities on the breast and non-puerperal secretion. Patients under 40 years of age who participated in an intensified screening program for genetically predisposed patients and high risk patients were also included. Women with self-detected breast cancer were excluded, as well as women who had a history of malignant or premalignant lesion and women during pregnancy or lactation. Male participants were not included in the study. After written informed consent, an interview based on a standardized questionnaire was performed and blood samples were taken on the day of the mammography. Histopathologic results of patients who received biopsies for histologic clarification and the results of patients who went on to have surgery were documented on paper. All data were extracted to Microsoft Excel tables and analyzed with IBM SPSS software. The protocol of the 

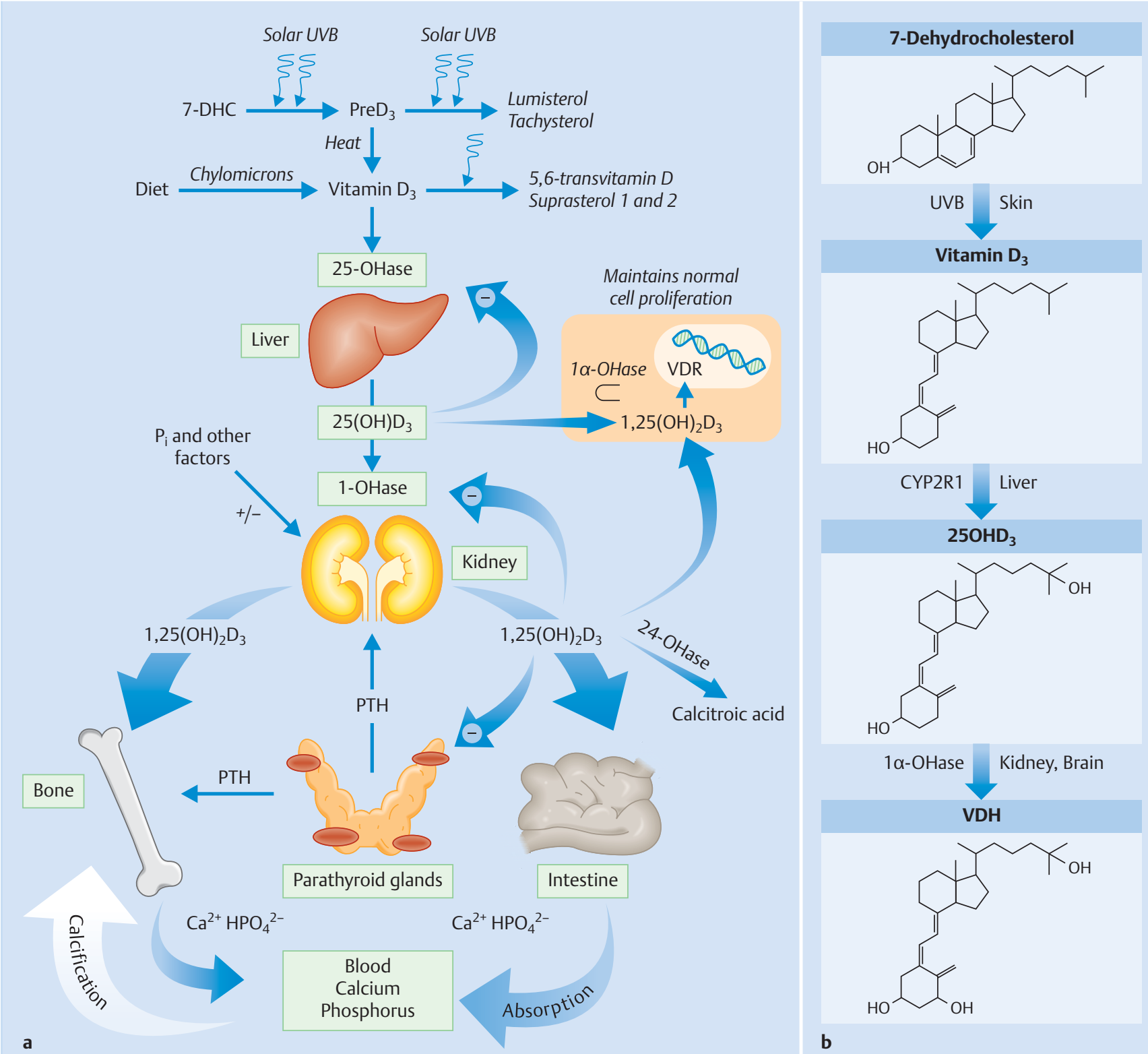

b

Fig. $1 \mathbf{a}$ and $\mathbf{b}$ a Schematic overview of vitamin D-metabolism and the influence on calcium-homoeostasis (modified from Holick 2004 [23]). Abbreviations: 7-DHC = 7-dehydrocholesterol; PreD = Previtamin D3; $25(\mathrm{OH}) \mathrm{D}=$ 25-Hydroxy-vitamin D; 1,25(OH)D = 1,25-Dihydroxy-vitamin D; VDR = Vitamin $\mathrm{D}$ receptor; $\mathrm{PTH}=$ parathyroid hormon; $\mathrm{Pi}=$ intracellular phosphate concentration. b Structure formulas of the vitamin D precursor 7-dehydrocholesterol (7$\mathrm{DHC}$ ), the reservoir form of vitamin $\mathrm{D}, 25-\mathrm{OH}-\mathrm{D}_{3}$ and the activated hormone form 1,25-OH-vitamin $\mathrm{D}_{3}$. UVB = Ultraviolet $\mathrm{B}$ solar radiation; $\mathrm{CYP2R} 1=$ vitamin D 25-hydroxylase; $1 \alpha$-OHase $=25$-hydroxyvitamin $D_{3} 1 \alpha$-hydroxylase [32]. study had been approved by the ethics commitee of the medical faculty of the TU Munich.

\section{Questionnaire}

The questionnaire included questions regarding the general medical and gynecological history, as well as known risk factors for breast cancer and questions concerning nutrition and life style of the patients. Food intake (dairy products, fish, etc.) and sunlight exposition as well as the use of sunblocking agents were summarized semiquantitatively as "frequent", "sometimes" or "rare". Patients were recruited from October until June. No patients were recruited during the summer months July, August and September to exclude bias by the strong elevation of vitamin
D due to the elevated sunlight exposition during summer [18]. Further questions referred to smoking habits and alcohol consumption. The body mass index (BMI in $\mathrm{kg} / \mathrm{m}^{2}$ ) was calculated from self-reported body weight and height. Physical activity and intake of vitamin D as well as self-medication with calcium were also documented. Age at menarche and - if appropriate - age at menopause were noted, as well as the date of the last menstrual bleeding. Women without hysterectomy were defined as postmenopausal according to the WHO definition if their last period dated back one year or longer. Women who were currently under hormone replacement therapy were excluded. Pregnancies (both miscarriages and full-term pregnancies), hysterectomy and/or unilateral or bilateral ovarectomy were recorded with the year 
Table 1 Baseline characteristics and lifestyle factors of participants with malignant histology and without.

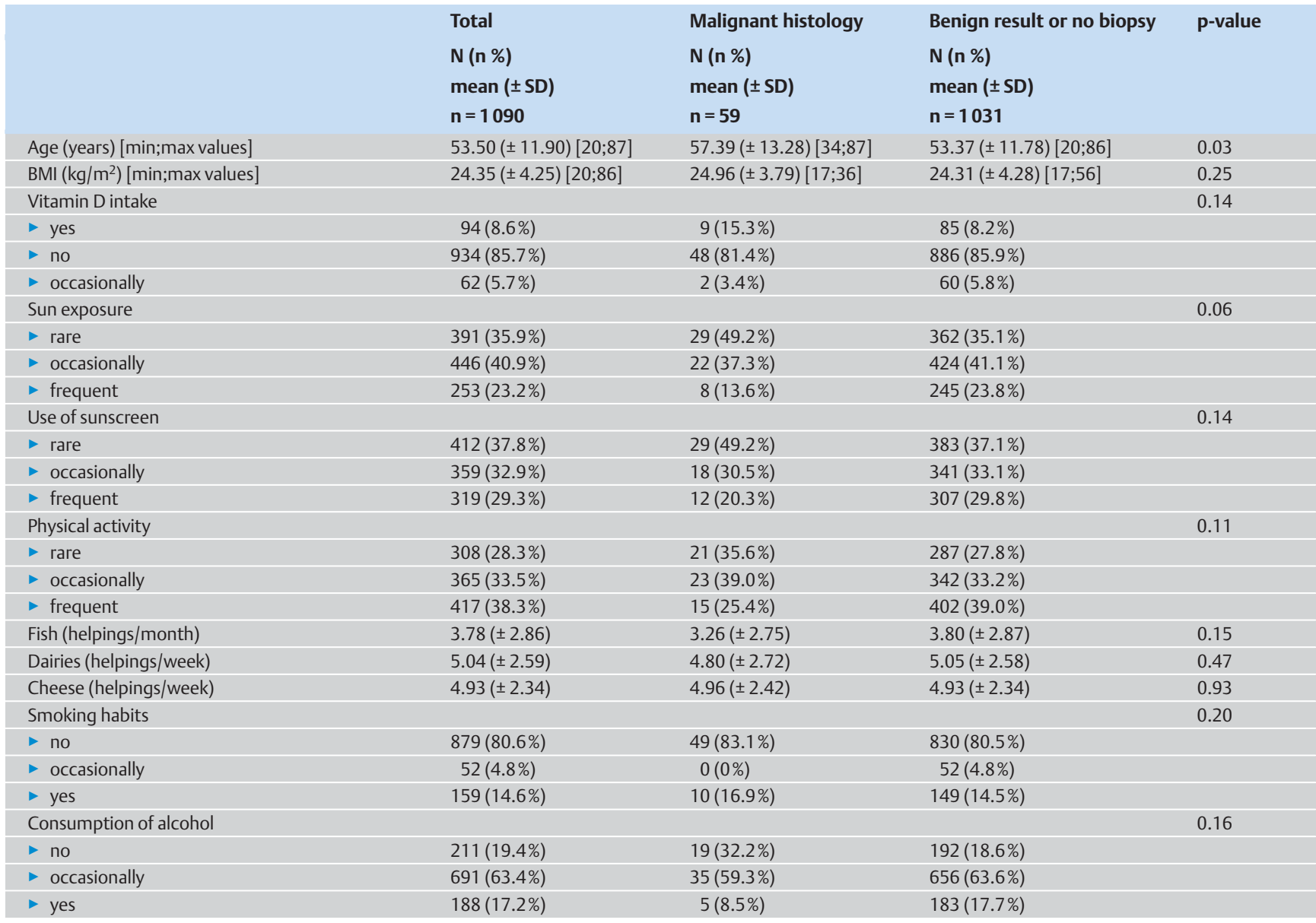

$N(n \%)$ : absolute frequency (relative frequency); MW ( \pm SD): mean ( \pm standard deviation); p-value: probability of error; two-sided significance for differences between the subgroups; t-test or $\mathrm{X}^{2}$-Test were applied according to whether the variables were ordinal or categorial.

of surgery if applicable. Prior breast disease - including inflammation of the breast and/or breast surgery for benign indications - were documented.

\section{Vitamin D measurements}

Vitamin D probes were delivered to the department of clinical chemistry within 6-8 hours of sampling, deep-frozen and later measured in batches, using a competitive 25(OH)D1,25 VD3-RIA with high specificity (and low cross-reactivity with other metabolites) by Dia Sorin.

\section{Statistical analysis}

Data were collected in Microsoft excel tables and analyzed using SPSS Statistics Version 21. Descriptive statistics were used for baseline characteristics, mammographic, histologic and laboratory findings. To assess the influence of independent variables on the breast cancer risk, t-testing was employed for interval-scaled, normally distributed variables, and Chi-Square testing for categorical variables. P-values $<0.05$ were considered significant.

\section{Results}

1103 women were recruited between September 2009 and June 2010, 1090 participants were included in the analysis. 13 women withdrew their informed consent or had to be excluded. Results reported here refer to the total group ( $n=1090)$, unless otherwise noted. Patients with malignant histological results $(n=59)$ were older ( 57.4 years $[ \pm 13.3 \mathrm{SD}])$ than the total group (53.5 years $[ \pm 11.9 \mathrm{SD}])(\mathrm{p}=0.03)$. The body-mass-index (BMI) in the total group was $24.35 \mathrm{~kg} / \mathrm{m}^{2}( \pm 4.25 \mathrm{SD})$. Weight differences between the group with malignant $\left(24.96 \mathrm{~kg} / \mathrm{m}^{2}[ \pm 3.79 \mathrm{SD}]\right) \mathrm{vs}$. benign histology or no histology $\left(24.31 \mathrm{~kg} / \mathrm{m}^{2}[ \pm 4.28 \mathrm{SD}]\right)$ were small and not significant ( $\bullet$ Table $\mathbf{1}$ ).

\section{Vitamin D intake, sunlight exposure}

and use of sun protection creams

94 (8.6\%) of all participants, 9 (15.3\%) of the women with malignant histology and 85 without (8.2\%) took vitamin D regularly, $5.7 \%(n=62)$ occasionally, with no significant difference between groups. The doses did not exceed $1000 \mathrm{IU} / \mathrm{d}$. In the total group, 391 (35.9\%) participants stated rare, 446 (40.9\%) occasional, and 253 (23\%) frequent exposure to sunlight. Patients with malignant diagnostic findings had less sun exposure (rare: 29 [49.2\%], occasionally: 22 [37.3\%], frequently: 8 [13.6\%]) than patients with no 


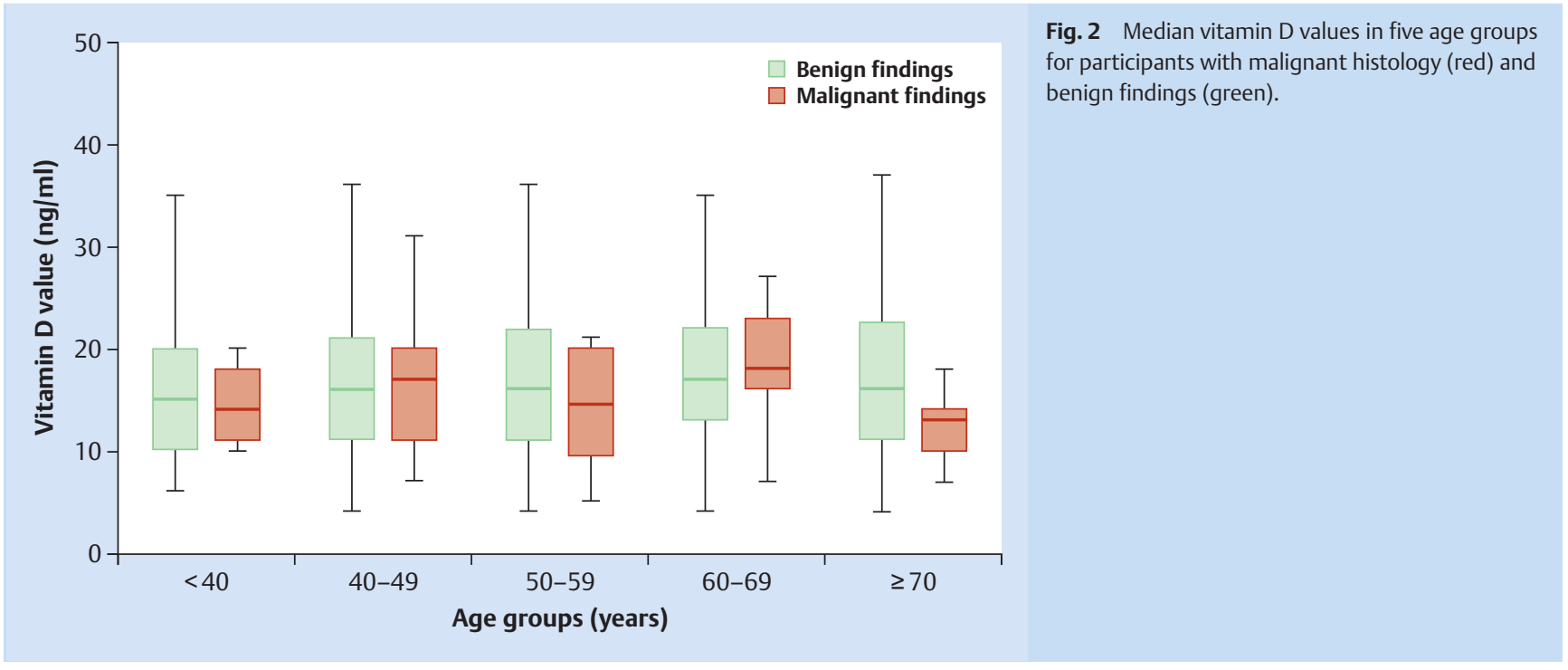

malignant findings (rare: 362 [35.1\%], occasional: 424 [41.1\%], frequent: 245 [23.8\%]) ( $p=0.06$ for the association of sunlight exposure with a malignant finding in the breast). $37.8 \%$ of all, versus $49.2 \%$ participants with a malignant finding used sun protection creams rarely, $20.3 \%$ to $29.8 \%$ of the women used sun protection frequently $(\mathrm{p}=0.14)$ (see $\bullet$ Table 1 ).

\section{Differences between age cohorts and variation by month of serum sampling}

The youngest women ( $<40$ years) had the lowest $25(\mathrm{OH})$-vitamin-D-values with an average of $15.17 \mathrm{ng} / \mathrm{ml}$. 107 women (9.8\%) were under 40 years of age ( 5 with a malignant, 102 with a benign result).

The highest vitamin D values were observed in participants aged 60-69 years, but average values for all age cohorts were below $20 \mathrm{ng} / \mathrm{ml}$ of vitamin D (see Fig. 2).

Average 25( $\mathrm{OH})$-vitamin-D values of the total group were under $20 \mathrm{ng} / \mathrm{ml}$ in most months. Only women recruited in November, reached $21 \mathrm{ng} / \mathrm{ml}$. The lowest values were found in March with an average of $14 \mathrm{ng} / \mathrm{ml}$ in 163 participants ( $\mathrm{p} \leq 0.001$ vs. other months). During the early summer months (May/June), women with malignant findings had remarkably low vitamin $\mathrm{D}$ averages with $12 \mathrm{ng} / \mathrm{ml}$ and $11 \mathrm{ng} / \mathrm{ml}$, compared with the rest of the group $(17 \mathrm{ng} / \mathrm{ml} ; 18 \mathrm{ng} / \mathrm{ml})$. Women with carcinomas mostly showed lower $25(\mathrm{OH}) \mathrm{D}$-values than those without, with an average delta of $4.06 \mathrm{ng} / \mathrm{ml}$ in women over 70 .

\section{Life style factors and gynecological history}

Exercise habits, consumption of dairy products or fish, smoking and drinking habits were slightly, but not significantly different between the groups. The complete results for baseline characteristics (age and BMI) and lifestyle factors are shown in $\bullet$ Table 1. Average age at menarche was 13.2 years $( \pm 2.0)$, with no difference between the groups (malignancy vs. not). Menopausal state was evaluable for 626 women, 446 participants were either pre-/ perimenopausal $(n=436)$ or the classification could not be made due to hormone therapy or being post-hysterectomy. 458 patients were postmenopausal, with a medium age at menopause of 50.4 years $( \pm 4.1)$. There was no difference in age at menopause between women with malignant histology and participants with benign clinical evidence $(\mathrm{p}=0.986)$. On average, postmenopausal women in this study were $9.65( \pm 8.49)$ years since menopause. The complete results for gynecological history are shown in 8 Table 2.

118 patients (10.8\%) stated that they took HRT due to climacteric complaints. In patients with a later malignant histology, the percentage was significantly less $(1.7 \% ; p=0.02)$ compared with women with a benign result (11.3\%). 218 participants (20\%) had previously had a hysterectomy. 11 (5\%) women had a malignant histological result after hysterectomy, this percentage was similar to that in the entire group. 67 women of the total group (6.7\%) were after bilateral ovarectomy. None of these patients had a malignant finding. 436 premenopausal patients provided information about the length of their menstrual cycle. Median length of the cycle was 31.3 days ( \pm 13.08 ), Participants with malignant clinical findings $(n=20)$ had a shorter length of the menstrual cycle (27.10 days $[ \pm 2.78]$; n. s.). The average age at first pregnancy was $26.2( \pm 5.7)$, with $(1.80( \pm 1.41)$ pregnancies and $1.46( \pm 1.24)$ births per woman with a malignant finding.

The participating women had experienced $1.17( \pm 0.42)$ breast inflammations and $1.26( \pm 0.64)$ breast operations for a benign indication. This rate did not differ between patients who now had benign or malignant results (see $\bigcirc$ Table 2 ).

454 participants ( $41 \%$ ) had a predisposition for breast- and ovarian cancer according to the familial risk criteria proposed by the consortium for familial breast cancer. This percentage was similar among patients with malignant evidence (35.6\% [n=21]) (data not shown).

\section{Vitamin D, calcium, phosphate and creatinine}

Average serum 25-OH-D in the total group was $17.09 \mathrm{ng} / \mathrm{ml}$ $( \pm 7.86)$ vs. $16.12 \mathrm{ng} / \mathrm{ml}( \pm 6.76)$ in participants with malignant histology (benign results $17.14 \mathrm{ng} / \mathrm{ml}( \pm 7.92)(\mathrm{p}=0.33)$. Serum calcium was slightly, but significantly higher in participants with malignant histology $(2.37 \mathrm{mmol} / \mathrm{l} \pm 0.12)$ than in the entire group ( $2.34 \mathrm{mmol} / \mathrm{l} \pm 0.09 ; \mathrm{p}=0.09$ ). Serum phosphate-values $(3.55 \mathrm{mg} /$ $\mathrm{dl} \pm 0.53)$ and creatinine values $(0.76 \mathrm{mg} / \mathrm{dl} \pm 0.15)$ were not different between the groups. $15.6 \%$ of all participants had vitamin D values < $10 \mathrm{ng} / \mathrm{ml}, 51.3 \%$ were vitamin D-deficient (10-19 ng/ $\mathrm{ml}$ ) and only $5.7 \%$ were above $30 \mathrm{ng} / \mathrm{ml}$, i.e. showed sufficient vitamin D. Patients with malignant results had vitamin $\mathrm{D}<10 \mathrm{ng} /$ $\mathrm{ml}$ more often $(16.9 \%$; $\mathrm{p}=0.61)$, were vitamin $\mathrm{D}$-deficient in 
Table 2 Gynecological and obstetrical history, hormonal factors, prior surgery and familial breast cancer risk.

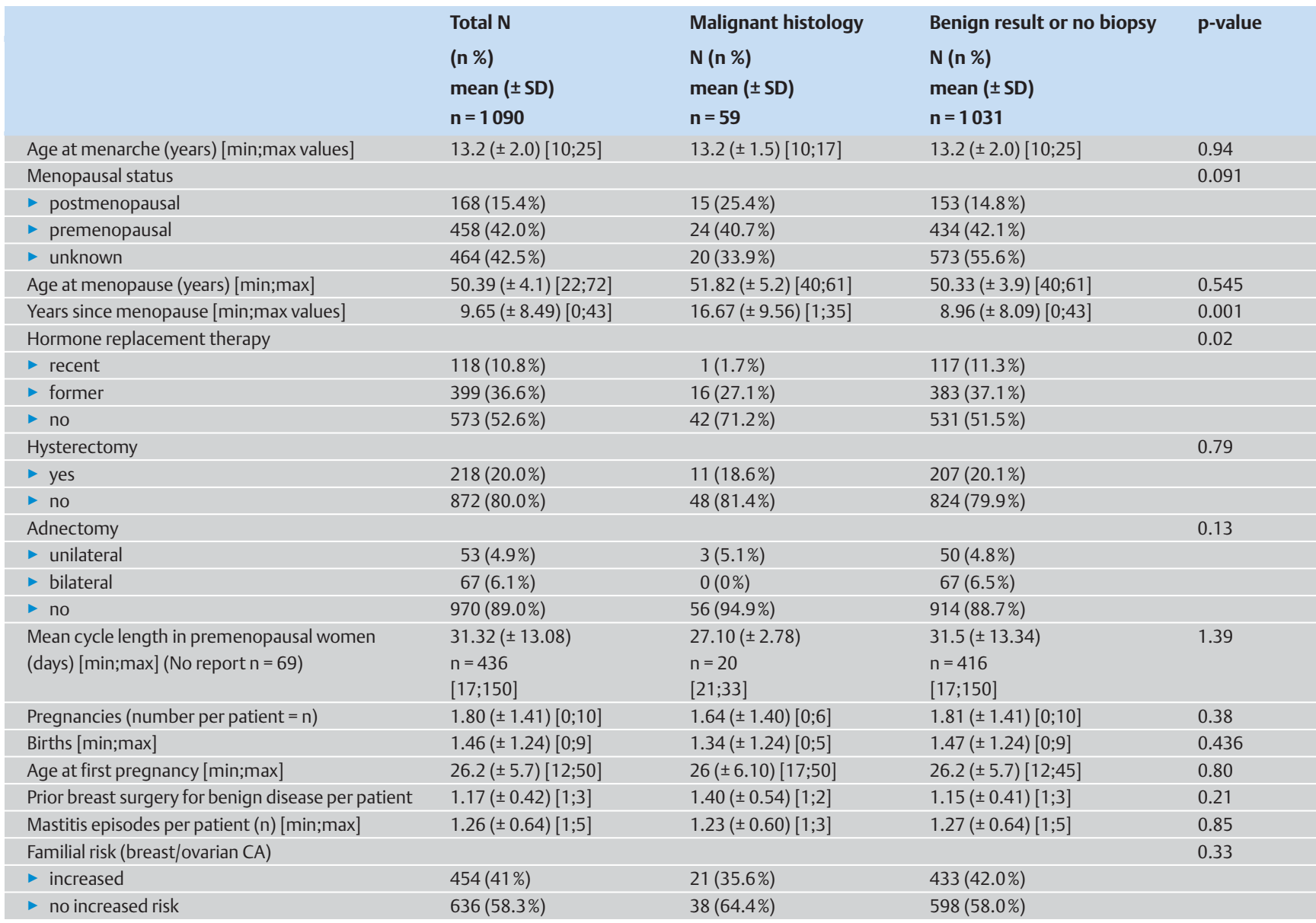

$\mathrm{N}(\mathrm{n} \%)$ : absolute frequency (relative frequency); $\mathrm{p}$-value: probability of error; two-sided significance for differences between the subgroups; $t$-test or $\mathrm{x}^{2}$-Test were applied as needed according to whether the variables were ordinal or categorial.

Table 3 Distribution of BIRADS - and ACR-Classification in the 999 participants with mammography.

\begin{tabular}{|c|c|c|c|c|}
\hline & $\begin{array}{l}\text { Total N } \\
\text { (n \%) }\end{array}$ & $\begin{array}{l}\text { Malignant histology } \\
\text { N (n \%) }\end{array}$ & $\begin{array}{l}\text { Benign result or no biopsy } \\
N(n \%)\end{array}$ & p-value \\
\hline BIRADS & $n=999$ & $n=59$ & $n=940$ & \\
\hline 0 & $69(6.9 \%)$ & $4(6.8 \%)$ & $65(6.9 \%)$ & \\
\hline 1 & $120(12.0 \%)$ & $0(0 \%)$ & $120(12.8 \%)$ & \multirow{5}{*}{$<0.001^{+}$} \\
\hline 2 & $618(61.9 \%)$ & $0(0 \%)$ & $618(65.7 \%)$ & \\
\hline 3 & $91(9.1 \%)$ & $3(5.1 \%)$ & $88(9.4 \%)$ & \\
\hline 4 & $61(6.1 \%)$ & $15(25.4 \%)$ & $46(4.9 \%)$ & \\
\hline $5 / 6$ & $40(4.0 \%)$ & $37(62.7 \%)$ & $3(0.3 \%)$ & \\
\hline ACR & $n=990$ & $n=56$ & $n=934$ & \\
\hline 1 & $84(8.5 \%)$ & $1(1.8 \%)$ & $83(8.9 \%)$ & \multirow{4}{*}{$0.078^{\# \#}$} \\
\hline 2 & $464(46.9 \%)$ & $24(42.9 \%)$ & $440(47.1 \%)$ & \\
\hline 3 & $345(34.8 \%)$ & $27(48.2 \%)$ & $318(34.0 \%)$ & \\
\hline 4 & $97(9.8 \%)$ & $4(7.1 \%)$ & $93(10.0 \%)$ & \\
\hline
\end{tabular}

\# p-value refers to differences in the distribution of BIRADS between the group with malignant histology and the other participants.

\#\#-value refers to differences in the distribution of ACR between the group with malignant histology and the other participants.

$N(n \%)$ : absolute frequency (relative frequency); $p$-value: probability of error; two-sided significance for differences between the subgroups; t-test or $\mathrm{X}^{2}$-Test were applied as needed according to whether the variables were ordinal or categorial. 
Table 4 Distribution of Vitamin D values in quantiles (Q1: extremely deficient, Q2: strongly deficient, Q3: mildly deficient and Q4: sufficient).

\begin{tabular}{|c|c|c|c|c|}
\hline & Total & Malignant histology & Benign result or no biopsy & p-value \\
\hline & $N(n$ \%) & $N(n \%)$ & $N(n \%)$ & \\
\hline & mean $( \pm S D)$ & mean $( \pm S D)$ & mean $( \pm S D)$ & \\
\hline & $n=1090$ & $n=59$ & $n=1031$ & \\
\hline Vit. D quantile 1: < $10 \mathrm{ng} / \mathrm{ml}$ & $170(15.6 \%)$ & $10(16.9 \%)$ & $160(15.5 \%)$ & \multirow{4}{*}{$p=0.614^{\#}$} \\
\hline Vit. D quantile 2: $10-19 \mathrm{ng} / \mathrm{ml}$ & $559(51.3 \%)$ & $34(57.6 \%)$ & $525(50.9 \%)$ & \\
\hline Vit. D quantile $3: 20-29 \mathrm{ng} / \mathrm{ml}$ & $299(27.4 \%)$ & $13(22.0 \%)$ & $286(27.7 \%)$ & \\
\hline Vit. D quantile 4: $\geq 30 \mathrm{ng} / \mathrm{ml}$ & $62(5.7 \%)$ & $2(3.4 \%)$ & $60(5.8 \%)$ & \\
\hline
\end{tabular}

$57.6 \%$ and only $3.4 \%$ in this group had sufficient vitamin D supply $>30 \mathrm{ng} / \mathrm{ml}(\mathrm{p}=0.614$ compared with women with a benign result).

\section{Mammography results}

999 participants received a Breast Imaging Reporting and Data System (BIRADS) classification in their mammography result. The other women received a breast ultrasound or breast MRT examination by indication. 59 participants later received a malignant histology by biopsy. Of these, 3 had had mammographies (5.1\%) classified as BIRADS III, $32 \%$ as BIRADS IV and $62.7 \%$ as BIRADS V or VI. 940 participants either needed no breast biopsy $(n=888$ ) or had a breast biopsy which showed a benign result $(n=52) .46$ women $(4.9 \%)$ with benign histology had received a BIRADS IV result, 3 had BIRADS V or VI. 88 women had BIRADS III (9.4\%); 120 participants had BIRADS I (12.8\%) and 618 BIRADS II (65.7\%).

Breast density according to ACR criteria was assessed for 990 participants (56 with malignant histology and 934 participants without). In the total group, $8.5 \%$ were classified as ACR $1 ; 46.9 \%$ as ACR $2 ; 34,8 \%$ as ACR 3 and $9.8 \%$ as ACR 4 . Patients with a malignant result had ACR 1 in $1.8 \%$, ACR II in $42.9 \%$, ACR III in $48.2 \%$ and ACR 4 in $7.1 \%$. Differences between groups were not significant ( Table 3).

\section{Discussion \\ $\nabla$}

Due to new research on the effects of vitamin D in carcinogenesis, the focus on a sufficient supply with this prohormone has increased, even beyond the well-known importance of vitamin D for bone health by ensuring adequate calcium-uptake in the intestine. Up to now, the existing definitions of insufficient or sufficient supply of vitamin D effects apply to the skeletal system only. For the last 4-5 years, a $25(\mathrm{OH}) \mathrm{D}$ level of $20 \mathrm{ng} / \mathrm{ml}(50 \mathrm{nmol} / \mathrm{L})$ is now considered insufficient [3]. According to the newest evidence-based data, a sufficient supply with vitamin $D$ exists when $25(\mathrm{OH}) \mathrm{D}$ serum-levels are $30 \mathrm{ng} / \mathrm{ml}(75 \mathrm{nmol} / \mathrm{L})$ or higher. This threshold was chosen due to the work of Bischoff-Ferrari, who showed that when the level is lower, a reactive increase of parathyroid hormone results, which may increase bone loss [19]. A supplementation of up to 10000 units of vitamin D daily is considered to be safe [20], intoxications with vitamin D are very rare. However, in less than one percent, an initial increase in calcium excretion with high doses of vitamin D may cause symptoms of hypocalcemia (such as muscle cramps) in patients.
These definitions however, do not concern cancer prevention. Up to now, there is no direct clinical evidence for a relationship between the risk for breast cancer and a specific vitamin $\mathrm{D}$ value, much less for the prevention of cancer by vitamin $D$ intake in randomized trials. Also, a possible association would not have to be linear but could be u-shaped. In our study, the vitamin D distribution over the months differed significantly in participants with benign clinical evidence $(\mathrm{p}<0.01)$. Patients with malignant results had low vitamin D levels around the year. However, the small number of patients with malignancy and the cross-sectional design are limitations of our study. A long-term follow-up of these patients for incident new malignancies over the ensuing years would be highly desirable.

Previous studies on the association between vitamin D and mammographic density have had conflicting results, as reported in a publication by Green et al. on their nested case-control study of mammographic density, vitamin D levels and risk of breast cancer in postmenopausal women from the Nurses Health Study [21].

The strength of that study was the much higher number of cases ( 463 vs. 497 controls), but the median time between mammography and vitamin D blood draw was 5 months (range: 20 months before until 1 month after) and summer months were not included. Among postmenopausal women in the highest tertile of mammographic density, there was a $48 \%$ reduced risk of breast cancer in women with a high versus low level of plasma $25(\mathrm{OH})$ D (OR: 05; 95\% CI, 0.3-0.9, p [trend]: 0.10). Statistical modelling in that study was performed with quartiles of vitamin $D$, which were slightly different for the three batches of probes measured by two different laboratories. Of note, the lowest quartile cutpoints were $9.0-23 \mathrm{ng} / \mathrm{ml}, 9-31 \mathrm{ng} / \mathrm{ml}, 6.2$ to $22.2 \mathrm{ng} / \mathrm{ml}$, i.e. $25 \%$ of all probes were in this range. The highest quartile started at 39 , 48 , and $36 \mathrm{ng} / \mathrm{ml}$ respectively, meaning that one quarter of all probes was in this range [21].

These values are much higher than those measured in our study. $66.9 \%$ of all participants in the study presented here had vitamin D levels under $20 \mathrm{ng} / \mathrm{ml}$, so that two thirds of our population would have fitted into the lowest quartile of Green's study. On the other hand, only $5.7 \%$ (or $3.4 \%$ for our "cases") in this southern German population were over $30 \mathrm{ng} / \mathrm{ml}$, a marked difference from the top $25 \%$ in the US-study ( $\odot$ Table 4 ).

Two forms of vitamin $\mathrm{D}$ can be absorbed by the body from exogenous sources: vitamin $\mathrm{D}_{2}$ or ergocalciferol, and vitamin $\mathrm{D}_{3}$. Ergocalciferol as a herbal ingredient is found in minor quantities in mushrooms and vegetables. Due to its low concentration and weak effect on the body, this intake of vitamin $D$ is practically 
meaningless [22]. Vitamin $\mathrm{D}_{3}$ on the other hand, derived from animal sources like dairy products, eggs as well as aliphatic fish (like salmon) is metabolised better by the human body. Nevertheless, in northern hemisphere countries, it is almost impossible to cover the need for vitamin D by nutrition only [31]. Therefore, some nations such as the USA try to meet the need for additional vitamin D supply for their population by enrichment of dairy products such as milk with vitamin D. Participants in the NHS nested case-control study reported above had an average daily vitamin D intake of between 311(Q1) and $440 \mathrm{IU}$ (Q4) from both food and supplements. This additional supply with vitamin D may partly explain the differences in vitamin $\mathrm{D}$ levels between Green's study and ours.

The same group around R. Tamimi recently extended their statistical model (tertiles of mammographic density, quartiles of vitamin D in serum, as previously applied in 2010 by Green [21]) to a sample of women who were premenopausal at the time of serum sampling. Evaluation of mammographic density was performed in the mammograms closest to the time of serum sampling with a range of 2 to 22 months between mammography and vitamin $D$ determination. The participants for this nested case-control study were taken retrospectively from two studies, the original Nurses Health Study (NHS), initiated in 1976 and the Nurses Health Study II, which began in 1989. Vitamin D samples were stored since 1990 for NHS and shorter for NHS II, breast cancer cases were noted until 2004 and 2007 respectively. Women in the top quartile of plasma $25(\mathrm{OH}) \mathrm{D}$ levels had an average percent breast density 5.2 percentage points higher (by Cumulus software) than women in the bottom quartile (95\% confidence interval: 1.8, 8.7; P trend <0.01), after adjusting for predictors of 25 $(\mathrm{OH}) \mathrm{D}$ and established breast cancer risk factors [32]. An inverse association between Vitamin $\mathrm{D}$ and breast cancer risk was apparent only among women with high mammographic density. Women with low mammographic density and low vitamin D concentrations had the lowest breast cancer risk in the multivariable risk analysis. Since women up to the age of 58 were included, and matching was \pm 2 years for age, and for menopausal status, a probability of change in menopausal status (which would have strongly affected mammographic density between the time of blood sampling and the evaluated mammograph) cannot be excluded in a substantial number of women, blurring these results. As in Green's study, the US women in Bertrand et al. had higher vitamin D levels than our German sample, with $50 \%$ showing values over $26.8 \mathrm{ng} / \mathrm{ml}$ - as opposed to only $5.7 \%$ over $30 \mathrm{ng} / \mathrm{ml}$ in our study, and $66.9 \%$ of women in our study with values below $20 \mathrm{ng} / \mathrm{ml}$ (note that this German study used quantiles and not quartiles) [32].

Another recent publication from Norway observed a "suggestive inverse association between vitamin $\mathrm{D}$ and mammographic density $(\mathrm{p}=0.03)$ " in an analysis restricted to women under 55 years of age. There were only 186 women who had had both a vitamin D measurement and a mammography (out of a total cohort of 3114 women who had completed a food questionnaire including vitamin D intake and had a mammogram). Again, the time span between mammography and serum sampling for Vitamin D was 2-3 years, which makes changes in menopausal status between the two very likely, particularly in women $<55$ years. In the publication by Ellingjord-Dale, participants were also classified in quartiles of vitamin $\mathrm{D}$ serum levels. The normal boundaries of these quartiles were as follows: Q1: $<34.9, \mathrm{nmol} / \mathrm{l}$, corresponding to $<14 \mathrm{ng} / \mathrm{ml}$, Q2: $34.9-43.8 \mathrm{nmol} / \mathrm{l}$, (corresponding to $14-$ $17.52 \mathrm{ng} / \mathrm{ml}$ ), Q3: $43.81-52.1 \mathrm{nmol} / \mathrm{l}$ (corresponding to $17.53-$
$20.84 \mathrm{ng} / \mathrm{ml}$ ) and Q4: $52.11-84.6 \mathrm{nmol} / \mathrm{l}$ (corresponding to $20.85-33.84 \mathrm{ng} / \mathrm{ml}$ ). The northern European women had a vitamin D distribution more similar than the US women to our southern German population, with $25 \%$ of the Norwegian participants showing values over $20 \mathrm{ng} / \mathrm{ml}$, compared to approximately $33 \%$ in our study). Interestingly, $75 \%$ of the Norwegian women had a daily intake of more than $6 \mu \mathrm{g}$ Vitamin D/day. No information on incident breast cancer diagnoses was published in this study [33].

The main source of vitamin $D$ is the endogenous production in the human skin by sunlight - this makes up for $90 \%$ of the cholecalciferol in the body [23]. The following factors can influence this endogenous production: the intensity of UV radiation, age, skin type, body fat (body mass index) and use of sun protection. UV radiation is essential for the formation of 7-dehydrocholesterol. Webb et al. showed an almost complete lack of vitamin D production during the months October until November north of the 42nd degree of latitude [24]. Apart from the fact that many elderly women (over 60 years) do not expose themselves to sunlight as much as they would need to, they also have lower 7-dehydrocholesterol reservoirs and therefore a decreased endogenous production of vitamin D. MacLaughlin et al. found only half the reservoir capacity for 7-dehydrocholesterol in skin biopsies of patients aged 77-82 years compared with participants between 8 and 18 years [25]. According to Holick et al., 70-yearold persons produce only $25 \%$ of the vitamin $D$ that 20 -year-olds produce under the same UV radiation [23].

Melanin reduces the UV-dependant step of vitamin D-synthesis. To gain a similar increase of circulating vitamin $\mathrm{D}$ as lightskinned persons, dark-skinned patients need 6 times more UVB radiation [26].

Obesity is associated with lower vitamin D serum levels [27]. The reason for this - besides lack of physical activity and the decreasing timespan obese children and adults spend outside - could be an unbalanced diet. As vitamin $\mathrm{D}$ is liposoluble, it is stored in adipose tissue and circulation in the body is therefore reduced [ 23 , 28]. Sun protection, be it by clothes or the use of sunmilk although important for melanoma prevention - decreases vitamin D production. Vitamin D production increased in thirty-seven healthy volunteers with fair skin types, the less sun protection was applied [29]. According to a study with 8 participants, SPF 8 already reduced endogenous vitamin D production by about $95 \%$ [30].

\section{Conclusion \\ $\nabla$}

Vitamin D has been associated with a reduced risk of breast cancer in epidemiologic and biologic studies. Studies conducted in the United States have suggested that while vitamin D does not influence the association between mammographic density and breast cancer, women with low vitamin $\mathrm{D}$ and high breast density were still at higher risk for breast cancer than women with high density and high vitamin D. In this southern German population of women aged 53.5 years on average, we found $66.9 \%$ vitamin values under $20 \mathrm{ng} / \mathrm{ml}$, which corresponds to the lowest quartile of vitamin D levels found in an US American cohort. In our study, the risk-difference by vitamin $D$ groups was not statistically significant, due to the small number of patients with malignancy. The data from the USA showed higher vitamin D values on average than in our study, possibly because milk is vitamin-D-fortified by UV-radiation in the US. Differences between women may 
therefore have been smaller in the US, possibly masking a possible pleiotropic effect. Therefore, a lack of evidence for a protective effect and recommendations against vitamin D for the prevention of breast cancer coming from the US may not hold true for Germany. Our data do not ground a recommendation for substitution. In the meantime, correction of very low vitamin D serum levels is accepted as a measure promoting bone health. Whether other clinical benefits, including a reduced risk of cancer, can be derived from enhanced vitamin D supply is being examined in ongoing clinical studies.

\section{Acknowledgements}

$\nabla$

This cross-sectional study was conducted with the support of a grant by the Bavarian state ministry for environment and health, (Staatsministerium für Umwelt und Gesundheit [StMUG]). J. Riedel was supported by a 6-month national scientific grant allocated through the TUM.

\section{Conflict of Interest}

$\nabla$

The authors have no conflict of interest.

\section{References}

1 Garland CF, Gorham ED, Mohr SB et al. Vitamin D for cancer prevention: global perspective. Ann Epidemiol 2009; 19: 468-483

2 Holick MF. The vitamin D epidemic and its health consequences. J Nutr 2005; 135: 2739S-2748S

3 Crew KD. Vitamin D: are we ready to supplement for breast cancer prevention and treatment? ISRN Oncol 2013; 2013: 483687

4 Zittermann A. Vitamin D: Cholecalciferol. In: Hermann ROW. Vitamins in the Prevention of human Disease. Homburg: De Gruyter; 2011: 363-395

5 Welsh J. Vitamin D and cancer: integration of cellular biology, molecular mechanisms and animal models. Scand J Clin Lab Invest Suppl 2012; 243: 103-111

6 Zinser GM, McEleney K, Welsh J. Characterization of mammary tumor cell lines from wild type and vitamin D3 receptor knockout mice. Mol Cell Endocrinol 2003; 200: 67-80

7 Sundaram S, Sea A, Feldman S et al. The combination of a potent vitamin D3 analog, EB 1089, with ionizing radiation reduces tumor growth and induces apoptosis of MCF-7 breast tumor xenografts in nude mice. Clin Cancer Res 2003; 9: 2350-2356

8 Welsh J. Induction of apoptosis in breast cancer cells in response to vitamin D and antiestrogens. Biochem Cell Biol 1994; 72: 537-545

9 Narvaez CJ, Welsh J. Role of mitochondria and caspases in vitamin Dmediated apoptosis of MCF-7 breast cancer cells. J Biol Chem 2001; 276: 9101-9107

10 Koli K, Keski-Oja J. 1alpha,25-dihydroxyvitamin D3 and its analogues down-regulate cell invasion-associated proteases in cultured malignant cells. Cell Growth Differ 2000; 11: 221-229

11 Larriba MJ, Valle N, Alvarez S et al. Vitamin D3 and colorectal cancer. Adv Exp Med Biol 2008; 617: 271-280

12 Carlberg C, Dunlop TW. The impact of chromatin organization of vitamin D target genes. Anticancer Res 2006; 26 (4 A): 2637-2645
13 Stumpf WE, Sar M, Reid FA et al. Target cells for 1,25-dihydroxyvitamin D3 in intestinal tract, stomach, kidney, skin, pituitary, and parathyroid. Science 1979; 206: 1188-1190

14 Horvath HC, Lakatos P, Kosa JP et al. The candidate oncogene CYP24A1: A potential biomarker for colorectal tumorigenesis. J Histochem Cytochem 2010; 58: 277-285

15 Swami S, Krishnan AV, Peng L et al. Transrepression of the estrogen receptor promoter by calcitriol in human breast cancer cells via two negative vitamin D response elements. Endocr Relat Cancer 2013; 20: 565-577

16 Krishnan AV, Swami S, Peng $L$ et al. Tissue-selective regulation of aromatase expression by calcitriol: implications for breast cancer therapy. Endocrinology 2010; 151: 32-42

17 McCormack VA, dos Santos Silva I. Breast density and parenchymal patterns as markers of breast cancer risk: a meta-analysis. Cancer Epidemiol Biomarkers Prev 2006; 15: 1159-1169

18 Woitge HW, Scheidt-Nave C, Kissling C et al. Seasonal variation of biochemical indexes of bone turnover: results of a population-based study. J Clin Endocrinol Metab 1998; 83: 68-75

19 Bischoff-Ferrari H. Vitamin D: what is an adequate vitamin D level and how much supplementation is necessary? Best Pract Res Clin Rheumatol 2009; 23: 789-795

20 Vieth R, Chan PC, MacFarlane GD. Efficacy and safety of vitamin D3 intake exceeding the lowest observed adverse effect level. Am J Clin Nutr 2001; 73: 288-294

21 Green AK, Hankinson SE, Bertone-Johnson ER et al. Mammographic density, plasma vitamin D levels and risk of breast cancer in postmenopausal women. Int J Cancer 2010; 127: 667-674

22 Armas $L A$, Hollis BW, Heaney RP. Vitamin D2 is much less effective than vitamin D3 in humans. J Clin Endocrinol Metab 2004; 89: 5387-5391

23 Holick MF. Sunlight and vitamin D for bone health and prevention of autoimmune diseases, cancers, and cardiovascular disease. Am J Clin Nutr 2004; 80 (6 Suppl.): 1678S-1688S

24 Webb AR, Kline L, Holick MF. Influence of season and latitude on the cutaneous synthesis of vitamin D3: exposure to winter sunlight in Boston and Edmonton will not promote vitamin D3 synthesis in human skin. J Clin Endocrinol Metab 1988; 67: 373-378

25 MacLaughlin J, Holick MF. Aging decreases the capacity of human skin to produce vitamin D3. J Clin Invest 1985; 76: 1536-1538

26 Clemens TL, Adams JS, Henderson SL et al. Increased skin pigment reduces the capacity of skin to synthesize vitamin D3. Lancet 1982; 1 : 1196-1199

27 Parikh SJ, Edelman M, Uwaifo GI et al. The relationship between obesity and serum 1,25-dihydroxy vitamin D concentrations in healthy adults. J Clin Endocrinol Metab 2004; 89: 1196-1199

28 Wortsman J, Matsuoka LY, Chen TC et al. Decreased bioavailability of vitamin D in obesity. Am J Clin Nutr 2000; 72: 690-693

29 Faurschou A, Beyer DM, Schmedes A et al. The relation between sunscreen layer thickness and vitamin $\mathrm{D}$ production after ultraviolet B exposure: a randomized clinical trial. Br J Dermatol 2012; 167: 391 395

30 Matsuoka LY, Ide L, Wortsman J et al. Sunscreens suppress cutaneous vitamin D3 synthesis. J Clin Endocrinol Metab 1987; 64: 1165-1168

31 Cekic M, Sayeed I, Stein DG. Combination treatment with progesterone and vitamin $\mathrm{D}$ hormone may be more effective than monotherapy for nervous system injury and disease. Front Neuroendocrinol 2009; 30: 158-172

32 Bertrand KA, Rosner B, Eliassen AH et al. Premenopausal plasma 25-hydroxyvitamin D, mammographic density, and risk of breast cancer. Breast Cancer Res Treat 2015; 149: 479-487

33 Ellingjord-Dale M, dos-Santos-Silva I, Grotmol T et al. Vitamin D intake, month the mammogram was taken and mammographic density in Norwegian women aged 50-69. PLoS One 2015; 10: e0123754 